\title{
Feasibility Study of RNPP (Rooppur Nuclear Power Project) in Bangladesh
}

\author{
Tausif Ali, Iftekhar Zaman Arnab, Saiful Islam Bhuiyan, Anik Rahman, \\ Iftekhar Hossain, M. Shidujaman \\ Dept. of Electrical and Electronic Engineering, American International University-Bangladesh, Dhaka, Bangladesh \\ Email: tau9097@gmail.com,iz.arnab@gmail.com
}

Received 2013

\begin{abstract}
Bangladesh is densely populated country with a population of 16 core and small area about 1, 47,570 Square-Kilometer. Among these large population only a few section are taking the blessings of power. But now at a stage government can't give the power even to that special section. Because day by day population is increasing and also power demands is also increasing. Governments are trying to meet up the power crisis in Bangladesh by taking various steps. Like small (10-20MW) power plants, IPP, Rental power plant etc. But these are not a permanent solution. More over these rental and IPP are mainly oil and gas based, which are very costly and not very efficient. Besides these government are going with coal based power station and small scale renewable energy. But coal based power station are required very large space, its initial cost is high and create serious environmental threat. Renewable energy is not yet developed and its efficiency is very poor. Though there are many problems and threats but Nuclear Power Plant can be a permanent solution for Bangladesh. Bangladesh government is now going for nuclear power plant and recently they have taken a project called Rooppur Nuclear Power Plant Project (RNPP) which is already approved in the cabinet meeting. The purpose of this paper is to study the feasibility of RNPP.
\end{abstract}

Keywords: Bangladesh; Nuclear; Power; Roopppur; Reactor; Radioactive; Pwr; Bwr; Desaster; Uranium; Security; Planning; Development

\section{Introduction}

The heart of nuclear energy Uranium was discovered in 1789 by Martin Klaproth, a German chemist, and named after the planet Uranus. The science of atomic radiation, atomic change and nuclear fission was developed from 1895 to 1945, much of it in the last six of those years. Over 1939-45, most development was focused on the atomic bomb. From 1945 attention was given to harnessing this energy in a controlled fashion for naval propulsion and for making electricity. Since 1956 the prime focus has been on the technological evolution of reliable nuclear power plants [1]. Nuclear provides about $6 \%$ of the world's energy and $13-14 \%$ of the world's electricity [2]. U.S., France and Japan together account for about $50 \%$ in nuclear generated electricity [3]. The IAEA reported there were 439 nuclear power reactors in operation in the world [4]. These nuclear power reactors are operating in 31 countries [5]. On June 27, 1954, the USSR's Obninsk Nuclear Power Plant became the world's first nuclear power plant to generate electricity for a power grid, and produced around 5 megawatts of electric power [6]. The world's first commercial nuclear power station, Calder Hall in Sellafield, England was opened in
1956 with an initial capacity of 50 MW (later 200 MW)[7]. The safety record of nuclear power is good when compared with many other energy technologies [8]. Research into safety improvements is continuing [9]. Besides this there are also some major accidents in $\mathrm{Nu}-$ clear Power plants. The Chernobyl disaster was a nuclear accident that occurred on 26 April 1986 at the Chernobyl Nuclear Power Plant in Ukraine (officially Ukrainian SSR), which was under the direct jurisdiction of the central Moscow's authorities. An explosion and fire released large quantities of radioactive contamination into the atmosphere, which spread over much of Western USSR and Europe. It is considered the worst nuclear power plant accident in history, and is one of only two classified as a level 7 event on the International Nuclear Event Scale [10]. The Fukushima Daiichi nuclear disaster is a series of equipment failures, nuclear meltdowns, and releases of radioactive materials at the Fukushima I Nuclear Power Plant, following the Tohoku earthquake and tsunami on 11 March 2011[11,12]. Fukushima disaster is the largest of the 2011 Japanese nuclear accidents and is the largest nuclear accident since the 1986 Chernobyl disaster, but it is more complex as multiple reactors and 
spent fuel pools are involved [13]. The Three Mile Island accident (1979) the most significant accident in the history of the USA commercial nuclear power generating industry, resulting in the release of approximately 2.5 million curies of radioactive gases, and approximately 15 curies of iodine-131[14]. Though there are some disadvantages but Bangladesh can be greatly benefited by establishing RNPP to meet up their recent power crisis with some consideration

\section{History of Rnpp}

A site for the first nuclear power plant in East Pakistan (now Bangladesh), was selected in a remote village called Rooppur in Pabna district in the western zone. There was no natural gas or any other indigenous energy resource in that zone at that time. Two independent electric power grids were built in the two zones of the province without any interconnection between them. The site at Rooppur, downstream of the Hardinge Bridge over the Ganges (Padma), was thus a natural choice for a nuclear power plant. Rooppur Nuclear Power project conceives in 1961 to meet the deficiency of future electric shortage. A number of feasibility studies had done before the liberation war of Bangladesh. After the liberation war selected site was taken for nuclear power plant project in Rooppur, Pabna. The selected land for the plant was 103.5 ha and the land for the rehabilitated people was 12.15 ha. There were three different projects approved by National Economic Council. They were 70MW in 1963, $140 \mathrm{MW}$ in 1966 and 200MW in 1969. Initial negotiations started in the early 1960s with USAID for a $70 \mathrm{MW}$ nuclear power Plant at Rooppur in 1963.As time passed, the reactor vendors were changed, the size of the power plant was increased and some feasibility reports were prepared, but no contract was signed. It is because the government of Pakistan was not concerned about the project. By this time in 1965 the contract for the construction of a 125 MW Pressurized Heavy Water Reactor(CANDU) in Karachi in West Pakistan, was signed with Atomic Energy of Canada Ltd. (AECL) without any feasibility study, even though there was a cabinet decision to build the first nuclear power plant in Pakistan at Rooppur. Several senior engineers and the Project Manager of the Rooppur Nuclear Power Project were transferred to the Karachi Nuclear Power Plant (KANUPP), thus crippling the Rooppur project. In 1968, PAEC received a proposal from V/o Technopromexport of Moscow to supply a 400 MW Pressurized Water Reactor (PWR) nuclear power plant with two turbines of 200MW each for Rooppur. At the same time a Beigial firm submitted a project proposal for a 200MW PWR plant in 1969.This offer appeared to be more attractive than the Russian one in view of the small size of the grid in the western zone of East Pakistan and some unresolved safety issues of the Russian reactor. It may be mentioned here that the proposed Russian reactor did not have any containment building, an essential safety feature designed to contain any release of radioactivity to the atmosphere in case of a nuclear accident. All the terms and conditions of the supply, construction and erection of the nuclear power plant were finalized with WENESE and the contract was due to be signed in early 1971.But after the liberation war the project was not in service due to the effect of after war financial crisis. A French consulting firm started a feasibility study in 1977 and finished it in 1978 with a conclusion that Rooppur project is suitable for 125 MW Reactor. The contract was signed in 1979.The executive committee of national economic council gave approval of $125 \mathrm{MW}$ project. But the funding source from Saudi Arabia was failed to finance the project due to some reasons. Latter on from 1987-1988 M/S Lahmeyer of Germany and M/S Motor Columbus of Switzerland conducted the latest study and unfortunately this project was also failed. After receiving the positive response of IAEA, Bangladesh Government decided the rooppur power plant on its own concept. At last 24th February, 2011 Bangladesh government signed a primary deal with Russia for installing a 2000 MW nuclear power plant at Rooppur in Pabna. By signing the deal, the government launched country's first nuclear power plant project (NPP) which would be completed in 2017-18 at the cost of US\$ 1.5 to 2 billions.

\section{Safety and Security Consideration for RNPP}

To establish the nuclear power plant in Bangladesh safety and security is a major consideration from the view of its small $(1,47,570 \mathrm{Sqr}-\mathrm{Km})$ densely populated and geographical area, proper site selection, Water management, natural disaster etc.

The first and major consideration to set a RNPP is the area and density of the people. According to the international law the radius of the area of nuclear power station is $30 \mathrm{Km}$. The area is divided in to three circular zone with $3.14(30) 2=2,826 \mathrm{Sqr} \mathrm{Km}$ area. According to the zone, zone- 1 is reactor area, zone- 2 is security area and zone- 3 is for planning disaster. The area of zone- 1 is a circular area of 3.14 Sqr Km. This area is only for the people who are working with reactors, others entrance is strictly prohibited. The distance of zone- 2 is $5 \mathrm{Km}$ away from the center and the total area of is 3.14 (5)2=78.5Sqr Km. This area is prohibited for agriculture and industries and only 3 people can leave per Sqr Km that is the total people of that zone will be only 200.The distance of zone-3 is $30 \mathrm{Km}$ from the center. This $30 \mathrm{Km}$ area must be free of population. If there are more people than there will be obstacles for rescuing the people. Developed countries nuclear power stations are free of population. That is for 
those reactors among $30 \mathrm{Km}$ is free from population. For example if there is an explosion in RNPP like Three Miles Island than people leaving there must be transferred 3.14(40)2=5024 Sqr Km area. So if 1000 people leave per Sqr Km then almost 1000000 people must me transferred from that area. It is quiet impossible. But the problem can be solved through changing some regulation. According to the international law some changes is applicable depending the situation. For example India has changed some regulation to build their nuclear power plant. The have changed the zonal area. The do this because they have the same problem of large population like Bangladesh. But there is a considerable think that as per there total country area the population is to very big. Therefore Bangladesh can their policy can be a little bit safe.

The second major problem is earthquake and natural disaster. From the experience of Fukushima Daiichi Nuclear Power plant in Japan 9.0 MW earthquake occurred at 14:46 JST on Friday, 11 March 2011 with epicenter near the island of Honshu [15]. It resulted in maximum ground accelerations of 0.56, 0.52, $0.56 \mathrm{~g}$ (5.50, 5.07 and $5.48 \mathrm{~m} / \mathrm{s} 2$ ) at Units 2, 3 and 5 respectively, above their designed tolerances of $0.45,0.45$ and $0.46 \mathrm{~g}$ (4.38, 4.41 and $4.52 \mathrm{~m} / \mathrm{s} 2$ ), but values within the design tolerances at Units 1, 4 and 6 [16]. When the earthquake occurred, the reactors on Units 1, 2, and 3 were operating, but those on Units 4, 5, and 6 had already been shut down for periodic inspection. Units 1, 2 and 3 underwent an automatic shutdown when the earthquake struck. When the reactors shut down, the plant stopped generating electricity, stopping the normal source of power for the plant. The situation at impacted nuclear reactors is, in the words of IAEA, an "Accident with Local Consequences." The Japanese earthquake and tsunami are natural catastrophes of historic proportions. The tragic loss of life and destruction caused by the earthquake and tsunami will likely dwarf the damage caused by the problems associated with the impacted Japanese nuclear plants. From the experience of Japan Bangladesh is in an earthquake zone and Bangladesh experienced the four major earthquakes between 7-8.5 Mw. So there is a threat for nuclear power plant in Bangladesh. The subsoil investigations, geotechnical, site specific seismic hazard assessment are the specific areas for major consideration for the selection of the site. According to the seismic zoning map Bangladesh is divided in to zone-1, zone-2 and zone-3.Rooppur site is in zone-3 which is seismically quiet. No indication of surface faulting around RNPP has been realized. The peak ground acceleration (PGA) is estimated $0.18 \mathrm{~g}$ for the return period of 2475 years which is much smaller than the designed basis PGA values of nuclear reactors. From the seismic hazard analysis and sub-soil investigation, any heavy structure like RNPP with the design basis
PGA values above $0.2 \mathrm{~g}-0.25 \mathrm{~g}$ could withstand a 7.5-9.5 Mw earthquake and can damage the RNPP in future.

Experience from Japan tsunami is also a consideration for Bangladesh to establish nuclear power plant. But it is great relive for Bangladesh that the site which is selected for RNPP is out of tsunami. Most of the experts said that Bangladesh may face tsunami in the Bay of Bengal which can generate $7 \mathrm{Mw}$ in rector scale and may cause serious threat. If the earthquake occurred at a level of $7.5 \mathrm{Mw}$ then sea level of Nijhom Dip Island will be raised by 4-5 meter. The water level will raise 2-3 meter $s$ in Cox's Bazar, Sundarban, Hatia and estuaries of Meghna .So these areas will be highly affected during tsunami. On the other hand RNPP will be located in Pabna which is situated in the South-Western Region of Bangladesh and there is no big and wide river which will affect the nuclear power plant even though there is tsunami.

The waste from nuclear power plant in Rooppur is a major consideration. The waste from nuclear power plant will be radioactive and the wastes will be radioactive. Radioactive wastes are wastes that contain radioactive material. Around 20-30 tons of high-level wastes is produced per month per nuclear reactor. There are some 65,000 tons of nuclear waste now in temporary storage throughout the U.S., but in 2009, President Obama "halted work on a permanent repository at Yucca Mountain in Nevada, following years of controversy and legal wrangling”[17]. There are three types of waste. High -level, Mill Tailings and Low level waste. Among these high level waste is most dangerous. During fission, very harmful radiation rays are released. The most harmful of which are gamma rays. When the human body is exposed to radiation, it can cause tumors and can do extreme damage to the reproductive organs. For this reason, problems associated with radioactivity can be passed on to the victim's children as well. That is why radioactive waste produced by nuclear power plants is so dangerous. Radioactive fission products could pose a direct radiation hazard, contaminate soil and vegetation, and be ingested by humans and animals. Human exposure at high enough levels can cause both short-term illness and death, and longer-term deaths by cancer and other diseases. So it has seen that radioactive waste can cause a great herm in Bangladesh if any disaster is occur in the future nuclear power plant. But there is nothing to be worried about it. Because there are new waste disposal technologies invented now a days. Bangladesh can use Experimental Breeder Reactor II.A breeder reactor is a nuclear reactor that generates more fissile material in fuel than it consumes. Breeder Reactor II is being developed by Argonne National Laboratory in the US; almost $100 \%$ of the transuranic nuclear wastes produced through neutron capture can be caused to fission. Generally, the fission products created have shorter half-lives and are not as 
dangerous. This reactor, dubbed EBR-II, uses liquid sodium as a coolant, which means that the internal reactor temperature is much, much hotter than that of a normal PWR reactor, which uses water as a coolant. Another advantage of EBR-II is that its fuel is not weapons grade quality. When the transuranic wastes are separated from the other wastes in the spent fuel rods, the resultant mix of isotopes can not be used in a bomb. Thus, the mix can be used as fuel for EBR-II without a chance of it getting stolen by a terrorist group for use in an explosive device. Breeder reactors "breed" fuel. That is, they are designed to create $239 \mathrm{Pu}$ from $238 \mathrm{U}$ through neutron capture. This "waste" can then be used as fuel.

Terrorism is a great threat for Bangladesh. If RPP is implemented in this country, then there will be a threat of nuclear terrorism. So security will be a major consideration. According to the CRS report for congress (Received through the CRS Web) nuclear power plants licensed by NRC must be protected by a series of physical barriers and a trained security force. The plant sites are divided into three zones: an "owner controlled” buffer region, a "protected area," and a "vital area.” Access to the protected area is restricted to a portion of plant employees and monitored visitors, with stringent access barriers. The vital area is further restricted, with additional barriers and access requirements. The security force must comply with NRC requirements on pre-hiring investigations and training. Bangladesh Government can follow their security policy for tight security. A terrorist attack on a nuclear research facility or commercial nuclear power plant could lead to the release of nuclear material. So to withstand the terror attack Bangladesh government can make a taskforce with civil and defense high officials to protect the future nuclear power plant in Bangladesh. After the 1979 accident at the Three Mile Island nuclear plant Congress required that all nuclear power plants be covered by emergency plans. NRC requires that within an approximately 10-mile Emergency Planning Zone (EPZ) around each plant the operator must maintain warning sirens and regularly conduct evacuation exercises monitored by NRC and the Federal Emergency Management Agency (FEMA).So Bangladesh can also keep the option of Emergency Response for the future RNPP.

\section{Technological Evaluation}

Day by day nuclear power technology is developing. After Genaration-1, 2 \&3 now at the latest moment fourth Generation technology is available. Various types of GEN-3 and GEN-4 pressurized water reactors are available and the most common are the advance PWR of Mitsubishi, Japan, CANDU of Atomic Energy Canada Limited, VVER(The VVER is the Russian version of the Pressurized Water Reactor (PWR). There are 3 standard designs - two 6 loop- 440 Megawatt [440-230 (older) and 440-213 (newer)] and 4 loop-1000 Megawatt output designs. As with PWRs, refueling is conducted with the plant shutdown, Europeans pressurized reactor of Siemens, France; AP-1000, USA etc. Among the GEN-3 reactors the VVER have been built in Taiwan and are being built in India.GEN-2reactors can be suitable for Bangladesh but it is not the better option. There are two major Generation II reactors that are, quite simply the basis for nuclear energy. These are the Pressurized Water Reactor (PWR) and the Boiling Water Reactor (BWR). There are some disadvantages of GEN-2 reactors. Because this is a pressurized reactor, rather than a boiling water reactor, water must be held at high pressures to keep from boiling, Fission product activity in the core builds up to high a level; Uranium must be enriched, which is a fairly expensive process; A double loop system is required, Because there is a double loop system, there is considerable heat lost in the heat transfer, adding to inefficiencies; Danger in primary loop, in that the water would vaporize to steam if there was a rupture in the system; Inefficient reactivity at the operating temperature; In order to replenish the core with new enriched Uranium, the plant must be shut down; The water coolant has a tendency to react with the Uranium and other materials, possibly causing safety risks. Considering these disadvantages Bangladesh should built the GEN-3 or GEN-4 reactors with a consideration of system simplicity, economic competitiveness, economic benefits, economic liability, safety consideration, digital instrumentation and control system, compliments for the latest safety code for the consideration of severe accidents like Chernobyl and Fukushima disaster, Physical Protection and issues of nuclear security. So from the technical view Bangladesh should go Russian VVER-1000MW nuclear power.

\section{Conclusions}

At present Bangladesh is facing serious load shedding due to shortage of power generation. Thermal power plants and other small scale renewable energy sources are giving tackle only for short period. To overcome this power crisis Bangladesh government has taken some initiatives. For example, Rental power station and Quick rental power stations. But these power stations are mostly gas and furnace oil based. Among this, furnace oil is highly costly and government is giving large amount of substitute every year for this type of power plants. So rental and quick rental can not be a permanent and effective solution. To overcome this situation nuclear power plant can be an effective solution to overcome the power crisis of Bangladesh, though there are some security and environmental aspects. Bangladesh government should ensure energy security for future by establishing a nuclear power plant as earliest as possible. 


\section{REFERENCES}

[1] http://www.world-nuclear.org/info/inf54.html

[2] World Nuclear Association. Another drop in nuclear generation World Nuclear News, 05 May 2010.

[3] Key World Energy Statistics 2007. International Energy Agency. 2007. Retrieved 2008-06-21

[4] "Nuclear Power Plants Information. Number of Reactors Operation Worldwide," International Atomic Energy Agency. Retrieved 2008-06-21.

[5] "World Nuclear Power Reactors 2007-08 and Uranium Requirements,” World Nuclear Association. 2008-06-09. Archived from the original on March 3, 2008. Retrieved 2008-06-21.

[6] "From Obninsk Beyond: Nuclear Power Conference Looks to Future,” International Atomic Energy Agency. Retrieved 2006-06-27.

[7] Kragh, Helge. Quantum Generations: A History of Physics in the Twentieth Century. Princeton NJ: Princeton University Press, 1999, p. 286. ISBN 0691095523.

[8] World Nuclear Association. Safety of Nuclear Power Reactors.
[9] David Baurac, "Passively safe reactors rely on nature to keep them cool,” Logos (Argonne National Laboratory) Vol.20, No.1, 2002, Retrieved 2007-11-01.

[10] Black, Richard (2011-04-12). "Fukushima: As Bad as Chernobyl?” Bbc.co.uk. Retrieved 2011-08-20.

[11] “Japan's unfolding disaster 'bigger than Chernobyl," New Zealand Herald. 2 April 2011.

[12] "Explainer: What went wrong in Japan's nuclear reactors,” IEEE Spectrum. 4 April 2011.

[13] "Analysis: A month on, Japan nuclear crisis still scarring,” International Business Times (Australia). 9 April 2011, retrieved 12 April 2011.

[14] Rogovin, pp. 153.

[15] "Magnitude 9.0 - near the East coast of Honshu, Japan,” Earthquake.usgs.gov,Retrieved 17 March 2011.

[16] "Fukushima faced 14-metre tsunami," World Nuclear News. 24 March 2011. Retrieved 24 March 2011.

[17] Eben Harrell (August 15, 2011). "Bury Our Nuclear Waste - Before It BuriesUs,” TIME. 